\title{
Splitting expansion and palatal approach technique for implant placement in
}

\section{severely resorpted maxilla}

\author{
Técnica de separação e expansão e abordagem palatina "splitting expansion and palatal approach" \\ para colocação de implantes em maxilas severamente reabsorvidas
}

Técnica de expansión por división y abordaje palatino "splitting expansion and palatal approach"

para colocar implantes en maxilares severamente reabsorbidos

Received: 06/15/2021 | Reviewed: 06/24/2021 | Accept: 06/28/2021 | Published: 07/12/2021

\author{
Mauricio Aguirre \\ ORCID: https://orcid.org/0000-0001-6597-9844 \\ Universidad de Los Hemisferios, Equador \\ E-mail: mauroaguirrek@gmail.com \\ Gabriel Fiorelli Bernini \\ ORCID: https://orcid.org/0000-0002-5799-6393 \\ Faculdade FACOP, Brazil \\ E-mail: gabrielbernini@yahoo.com.br \\ Fernando Arciniegas \\ ORCID: https://orcid.org/0000-0002-5049-8738 \\ Universidad de Vera Cruz, Mexico \\ E-mail: ferarciniegas@gmail.com \\ Karina Maria Salvatore de Freitas \\ ORCID: https://orcid.org/0000-0001-9145-6334 \\ Centro Universitário Ingá, Brazil \\ E-mail: kmsf@uol.com.b
}

\begin{abstract}
The treatment of patients with atrophic maxillary alveolar ridge who need oral rehabilitation is a common problem in Implant Dentistry. One of the techniques used is the alveolar ridge splitting technique to expand alveolar ridges with a horizontal bone decrease. The palatal approach technique is also recommended in cases with an insufficient thickness of the alveolar ridge for the placement of implants in the bone envelope. The aim of this work is to describe the splitting expansion and palatal approach technique for the treatment of atrophic maxillary ridges with a horizontal bone deficit and rehabilitation with implant placement. This technique combines the alveolar ridge splitting/expansion technique and the palatal approach technique. It allows alveolar ridge expansion using piezosurgery and immediate placement of implants without thread exposure in the palatal aspect. With one surgical time, this technique avoids the fracture of the buccal bone plate due to the expansion, eliminates the need for bone graft and donor-site morbidity, is simple and effective, and shows great esthetic results and implant success.
\end{abstract}

Keywords: Dental implants; Implant placement; Maxillary atrophy; Palatal approach; Alveolar ridge splitting/expansion.

\section{Resumo}

O tratamento de pacientes com rebordo alveolar maxilar atrófico que necessitam de reabilitação oral é um problema comum em Implantodontia. Uma das técnicas utilizadas é a técnica de separação do rebordo alveolar para a expansão das cristas alveolares com diminuição óssea horizontal. A técnica de abordagem palatina também é recomendada em casos com espessura insuficiente da crista alveolar para colocação de implantes no envelope ósseo. O objetivo deste trabalho é descrever a técnica de separação e expansão e abordagem palatina para o tratamento de cristas maxilares atróficas com déficit ósseo horizontal e reabilitação com colocação de implantes. Essa técnica combina a técnica de separação e expansão da crista alveolar e a técnica de abordagem palatina. Permite a expansão do rebordo alveolar com o uso de piezocirurgia e colocação imediata de implantes, sem exposição de roscas no aspecto palatino. Com um tempo cirúrgico, essa técnica evita a fratura da tábua óssea vestibular devido à expansão, elimina a necessidade de enxerto ósseo e morbidade do local doador, é simples e eficaz e apresenta excelentes resultados estéticos e sucesso do implante.

Palavras-chave: Implantes dentários; Colocação de implante; Atrofia maxilar; Abordagem Palatina; Separação / expansão da crista alveolar. 


\section{Resumen}

El tratamiento de pacientes con reborde alveolar maxilar atrófico que necesitan rehabilitación oral es un problema común en Implantología. Una de las técnicas empleadas es la técnica de separación de crestas alveolares para expandir las crestas alveolares con reducción horizontal del hueso. La técnica de abordaje palatino también se recomienda en casos con un grosor insuficiente de la cresta alveolar para colocar implantes en la envoltura ósea. El objetivo de este trabajo es describir la técnica de separación y expansión y el abordaje palatino para el tratamiento de crestas maxilares atróficas con déficit óseo horizontal y rehabilitación con colocación de implantes. Esta técnica combina la técnica de separación y expansión de la cresta alveolar y la técnica de abordaje palatino. Permite la expansión del reborde alveolar con el uso de piezocirugía y colocación inmediata de implantes, sin exposición de roscas en la cara palatina. Con un tiempo quirúrgico, esta técnica evita la fractura de la placa ósea vestibular por expansión, elimina la necesidad de injerto óseo y la morbilidad del sitio donante, es simple y eficaz, y presenta excelentes resultados estéticos y éxito del implante.

Palabras clave: Implantes dentales; Colocación de implantes; Atrofia maxilar; Abordaje palatino; Separación / expansión de la cresta alveolar.

\section{Introduction}

The oral rehabilitation of patients with tooth loss and insufficient bone quantity is one of the great challenges in Implant Dentistry. The alveolar ridge remodeling process that occurs after teeth loss affects the bone thickness and height, which can compromise prosthetic rehabilitation with dental implants (Brandão et al, 2020).

The buccolingual alveolar ridge dimension decreases approximately $6 \mathrm{~mm}$ in thickness after one year of a tooth is lost (Schropp, Wenzel, Kostopoulos, \& Karring, 2003). Therefore, the amount of bone resorption can be up to $50 \%$ of the original bone width (Araujo \& Lindhe, 2009; Schropp et al., 2003).

In patients with several teeth loss, the edentulous alveolar ridge segment suffers more bone resorption. This way, surgical bone augmentation procedures with grafts is usually recommended (Buser et al., 2012). However, most of the treatment options, including bone grafts that increase time and costs, present more risks of dehiscences and infections and negatively affect patients' morbidity (Felice et al., 2009; Nkenke, Schultze-Mosgau, Radespiel-Troger, Kloss, \& Neukam, 2001).

In cases with bone resorption and a narrow ridge, the alveolar ridge splitting/expansion technique utilizing hand osteotomes with gradually increasing dimensions was introduced by Tatum (Tatum, 1986) and modified by Summers (Summers, 1994).

The alveolar ridge splitting/expansion technique was described as a longitudinal alveolar ridge splitting into two parts, provoking a greenstick fracture made with small chisels (Simion, Baldoni, \& Zaffe, 1992).

These procedures are recommended only in cancellous bone quality (types 3 or 4) and allow positioning of implants simultaneously and thus significantly shorten the treatment time(Bassetti, Bassetti, \& Bosshardt, 2016), and an alveolar ridge width of a minimum of 3 to $4 \mathrm{~mm}$ is required (Suh, Shelemay, Choi, \& Chai, 2005).

The limitations of these two techniques arise from the presence of highly compact residual bone and the lack of a cancellous bone layer between the oral and buccal cortical plates. However, with the introduction of the piezoelectric devices (Vercellotti, 2000) for cutting hard alveolar bone under adequate control, the alveolar ridge splitting technique for expansion can be used regardless of the bone quality.

The palatal approach technique is another alternative to edentulous or partially edentulous patients with severely atrophic alveolar ridges with insufficient thickness for implant placement in the bone envelope. The implants are installed on the palatal aspect of the remaining bone crest, obtaining the apical locking of the implants in the basal bone, usually with thread exposure in the palatal aspect of the implant (Lekholm, Sennerby, Roos, \& Becker, 1996). 
This work aims to describe the hybrid splitting expansion and palatal approach technique that combines the alveolar ridge splitting/expansion technique and the palatal approach technique, which is indicated to treat atrophic maxillary ridges with severe bone width loss for rehabilitation with implant placement.

\section{Description of the Technique}

For this technique to be performed, some conditions are needed: an anterior nasal spine with a minimum of $3 \mathrm{~mm}$ width and a triangular base; an anterior bone volume on the nasal spine of 3 to $4 \mathrm{~mm}$ in front of the nasopalatine canal; an alveolar ridge with a broad base and a knife-shaped crest with at least $10 \mathrm{~mm}$ of bone height and at least $3 \mathrm{~mm}$ of width at the crest and 4 to $5 \mathrm{~mm}$ at the base.

Antimicrobial prophylaxis with antibiotics is recommended. First, patients are anesthetized locally by infiltration anesthesia. Then, it is performed an incision for paracrestal palatal flap with palatal repair and a complete flap with the limit on the nasal cavity floor and buccal releasing incisions in the distal of the first molar region. Next, dissection of the full thickness mucoperiosteal flap is performed, providing complete exposure of the alveolar bone (Figure 1).

Figure 1. Complete flap with periosteum.

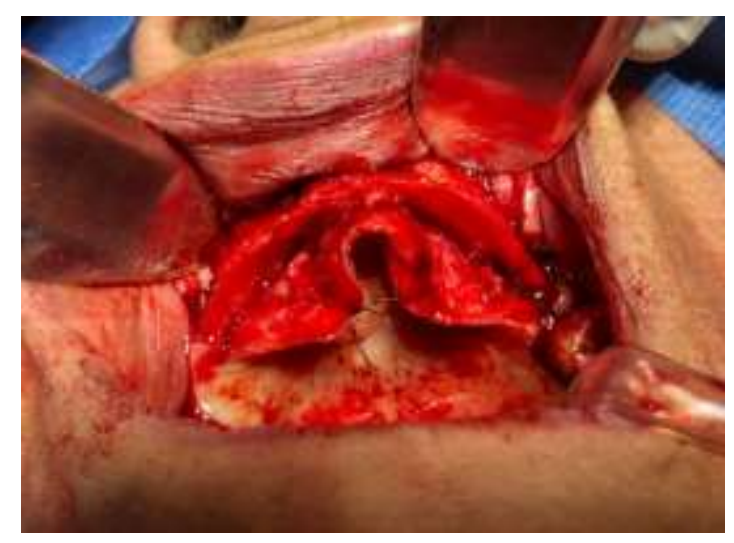

Source: Authors.

A flattening of the bone ridge edge is performed at a palatal angle of $45^{\circ}$ with a maxicut bur in a straight handpiece at $40,000 \mathrm{rpm}$ under constant cooling with saline (Figure 2). After the flattening at $45^{\circ}$, a bone incision is made under the palatal ridge with the piezoelectric device.

Figure 2. Flattening of the bone ridge with a palatal angle of $45^{\circ}$.

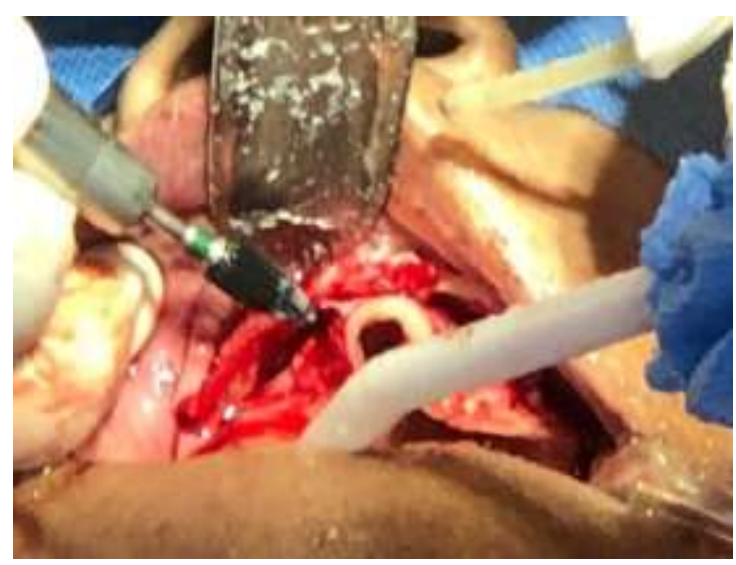

Source: Authors. 
The piezoelectric device (Dmetec SurgyStar Dental Ultrasonic Piezo Implant Bone Surgery Motor, Korea) is used with an angled ultrasound tip to generate a palatal ridge fracture line outlining the entire exposed crest with a depth of 3 to $5 \mathrm{~mm}$ where a triangular base with cancellous bone can be found (Figure 3 ).

Figure 3. The angled ultrasound tip generates a palatal ridge fracture line.

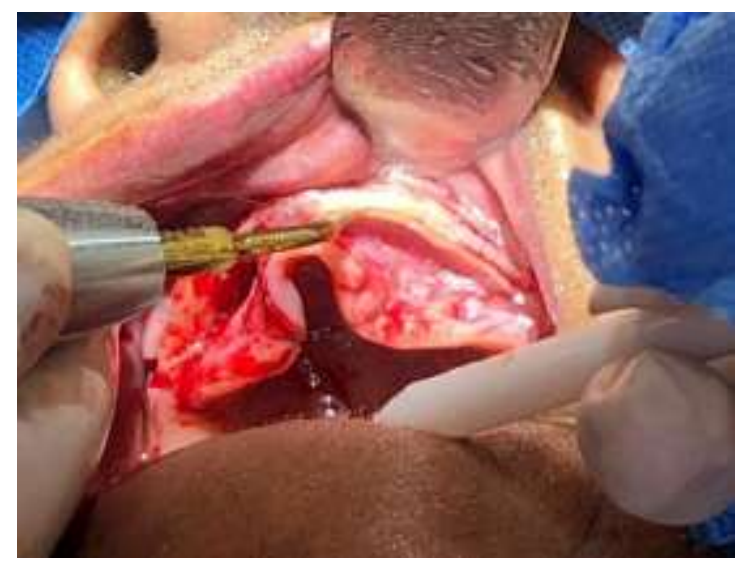

Source: Authors.

Then we proceed with the technique of drilling and expansion. The drilling is made with a spearhead in a rotation motor at $800 \mathrm{rpm}$ with refrigeration and performs the cutting to guide the expanders. The spearhead drill cutting is performed in the maxillary molar area, canine pillar and the lateral triangle of the nasal crest (maxillary central incisor region) to the depth of 13 to $15 \mathrm{~mm}$ on the palatal edge of the crest cut (Figure 4).

Figure 4. The spear drill was cutting in the canine pillar.

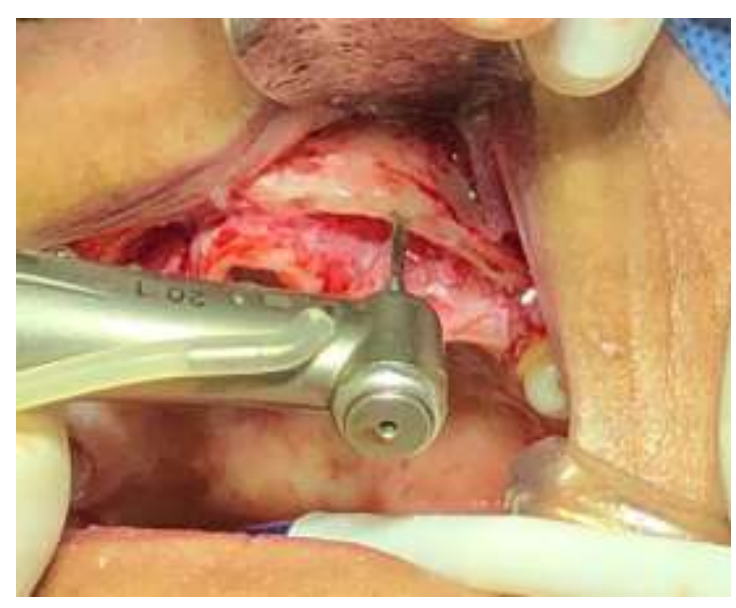

Source: Authors.

In depressions of the maxillary lateral incisors, it is important to perform a guide of anterior fracture on the anterior cortical with the piezoelectric from the ridge of the alveolar crest up to 6 to $8 \mathrm{~mm}$ approximately apical an approximate depth of $2 \mathrm{~mm}$. This way, the expansion can occur, reducing the risk of fracture of the buccal bone plate. Figure 5 shows the line of the sagittal fracture to the edge in the sector of buccal depressions between the canine pillar and nasal crest triangle. 
Figure 5. Detail of the sagittal fracture line in the buccal depressions between the canine pillar and nasal crest triangle.

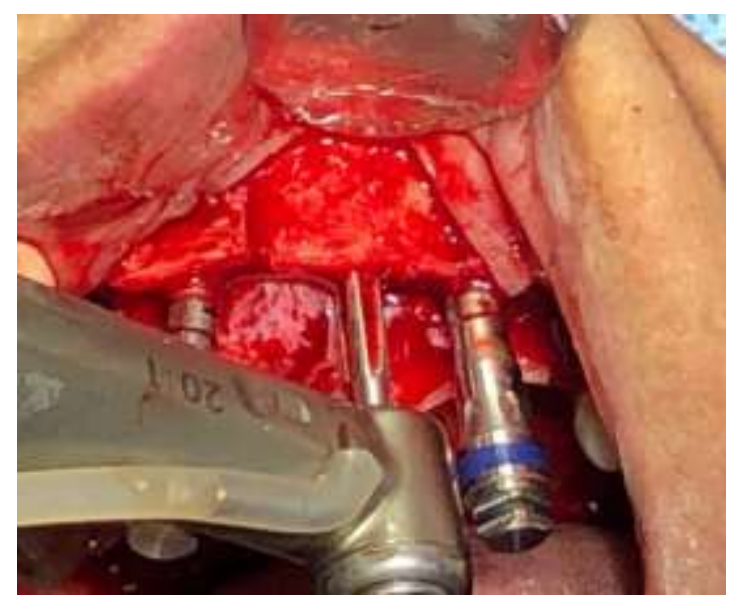

Source: Authors.

Number 2 expanders are placed ( $\varnothing$ tip 1.50mm; TO 3.00mm; Microdent Implant System, Barcelona, Spain), in three sites (maxillary molar area, canine pillar and nasal crest lateral triangle) where the drilling was performed at $2 \mathrm{~mm}$ beyond the crest size and of the measurement of the final implant placement, under the sinus floor (Figure 6). After placement of the three \#2 expanders, it is recommended to wait 3 to 5 minutes for the expansion to occur.

Figure 6. Placement of \#2 expanders in three places where the drilling is performed at $2 \mathrm{~mm}$ beyond the crest size and the final implant installation size.

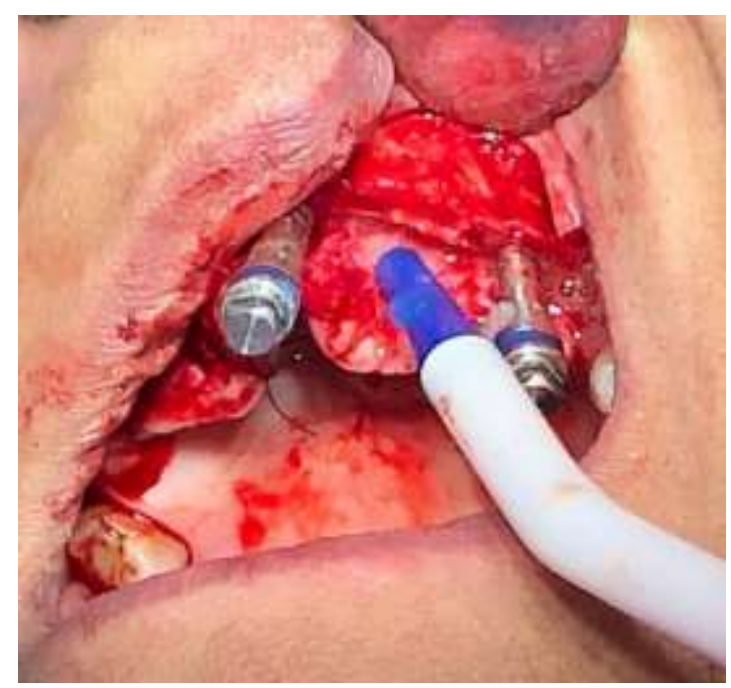

Source: Authors.

After this, the \#2 expander in the canine pillar is, and the expansion is maintained by the other two expanders. The surgical sequence is the $\varnothing 2.0 \mathrm{~mm}$ tip instrument drilled into the expanded socket until the nasal fossa floor is perforated $1 \mathrm{~mm}$ and a \#3 expander ( $\varnothing$ tip $1.90 \mathrm{~mm}$; TO $3.80 \mathrm{~mm} ; 8 \mathrm{~mm}=\varnothing 2.75 \mathrm{~mm} 10 \mathrm{~mm}=\varnothing 3.00 \mathrm{~mm} 12 \mathrm{~mm}=\varnothing 3.25 \mathrm{~mm} 14 \mathrm{~mm}=\varnothing 3.50 \mathrm{~mm}$; Microdent Implant System, Barcelona, Spain) is placed in the canine site. Maintaining this in the canine place, the drilling is performed with the $2 \mathrm{~mm}$ cutter in the molar alveolus until perforating maxillary sinus cortex at $1 \mathrm{~mm}$, the expander \#3 is placed in the molar site, the \#2 expander is removed of the central incisor site and the drilling cutter is performed with $2 \mathrm{~mm}$ instrument until the nasal fossa floor is perforated $1 \mathrm{~mm}$. The anchorage guide of the cutter at the apical level is the nasal fossa floor or the cortical of the maxillary sinus floor. 
Number 3 expanders are also inserted in the molar and incisor zone after the canine expander is placed. Then the \#3 expander is removed from the canine site, and the final drilling is made with a $2.8 \mathrm{~mm}$ tapered conical drill (Figure 7). After this, a $3.5 \mathrm{~mm}$ cone morse implant is installed in the canine pillar area (Microdent Implant System, Barcelona, Spain) (Figure $8)$.

Figure 7. \#3 expander in canine, molar and incisor region.

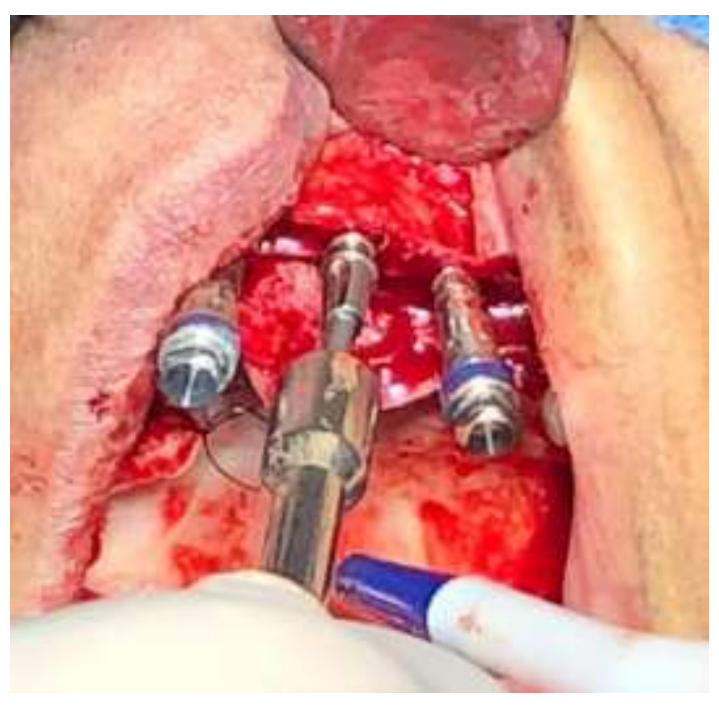

Source: Authors.

Figure 8. 3.5mm conical implant installed in the canine pillar.

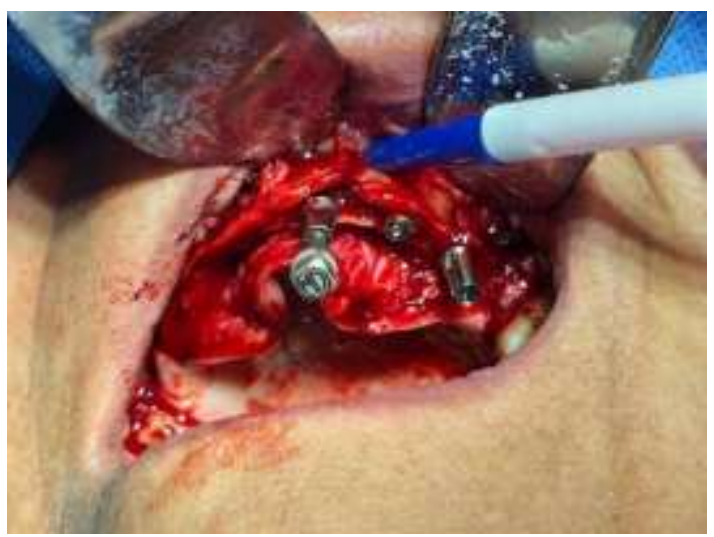

Source: Authors.

The final $\varnothing 2.8 \mathrm{~mm}$ drill is also used in the incisive and molar region, and a 3.5mm implant is installed (Figure 9). It can be observed the opening of the anterior fracture. Anterior nasal spine displacement is observed with the opening of the fracture lines. Greenstick fractures can occur in the molar region. 
Figure 9. 3.5mm implant installed in incisive, canine and molar region.

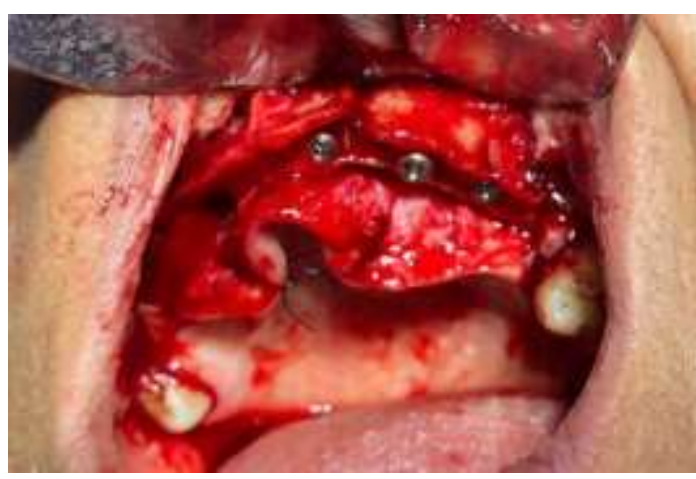

Source: Authors.

The anterior implants receive a more centered discharge, so it is possible to perform the drilling with a slight palatal inclination.

The expansion is performed to increase the alveolar ridge and drilling to create the implant tunnel by removing bone, decreasing the possibility of greater displacement of the bone plates, decreasing the risk of buccal bone plate fracture.

On the other side, the same drilling protocol, expansion and implant installation are performed (Figure 10). Again, it is recommended to use implants with a length of 11.5 to $13 \mathrm{~mm}$, and no less than $10 \mathrm{~mm}$.

Figure 10. All 6 implants of $3.5 \mathrm{~mm}$ were installed in the incisive, canine and molar region of both sides.

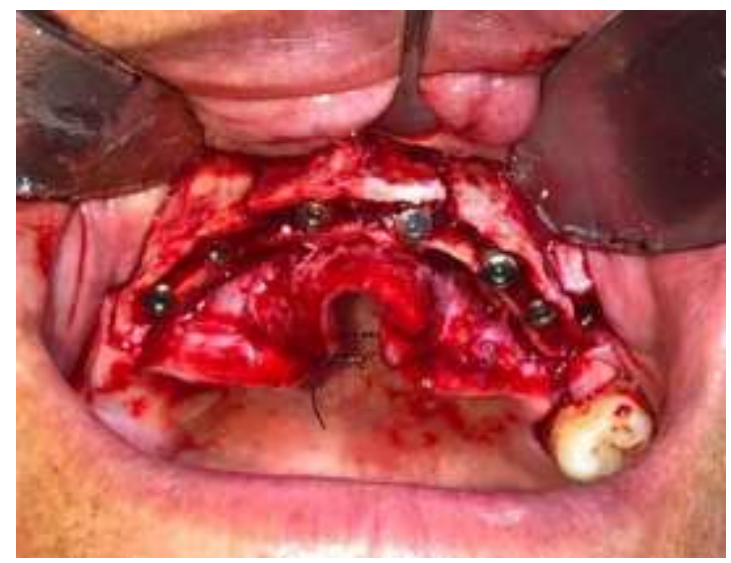

Source: Authors.

The implant is submerged from 2 to $3 \mathrm{~mm}$ from the anterior ridge so that if there is any degree of bone resorption, it should not be larger than $2 \mathrm{~mm}$, and the implant will remain stable and fully covered.

The primary stability of implants is achieved, and the flap is closed. As a result, the inferior limit of the implant can be anchored in cortical bone. If not possible, you should start slower the drilling to eliminate inner bone, preventing the buccal bone plate from fracturing.

The drilling exceeds the bone of the nasal fossa floor and maxillary sinus floor by $2 \mathrm{~mm}$ and enters about $1 \mathrm{~mm}$ into the sinus floor without damaging the mucosa and anchoring the implant to the cortical bone creating greater primary stability.

The soft tissue is sutured, and the implants are left submerged for healing (Figure 11). 
Figure 11. Suture performed.

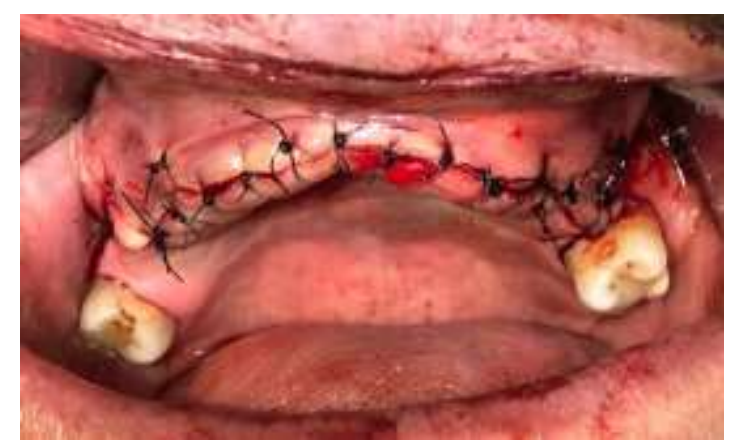

Source: Authors.

The fracture lines created decompress the bone plates and prevent them from fracturing in buccal areas of the implants, avoiding the need for bone grafts.

The technique primarily does not involve the use of PRP membrane-associated or not with bone grafting material. However, each case has to be evaluated individually, and the technique can be modified if necessary.

It is recommended for Class IV maxillary atrophic alveolar ridges, with sufficient height but with extensive horizontal bone resorption (knife-blade edge), where there is a need for an increase in the bone thickness (Cawood \& Howell, 1988). The alveolar ridge should be at least $3 \mathrm{~mm}$ wide (Suh et al., 2005) and triangular base.

Regarding the classification of the maxillary alveolar ridges, they are usually made three-dimensionally (Cawood \& Howell, 1988). For this technique, the ridge classification was modified from Cawood and Howell (Cawood \& Howell, 1988), and is based on a multidimensional concept from the biological point of view, taking into account the biology of nutrition and bone quality (Figure 12 and 13).

Figure 12. Multidimensional scheme of the hybrid splitting expansion and palatal approach technique.

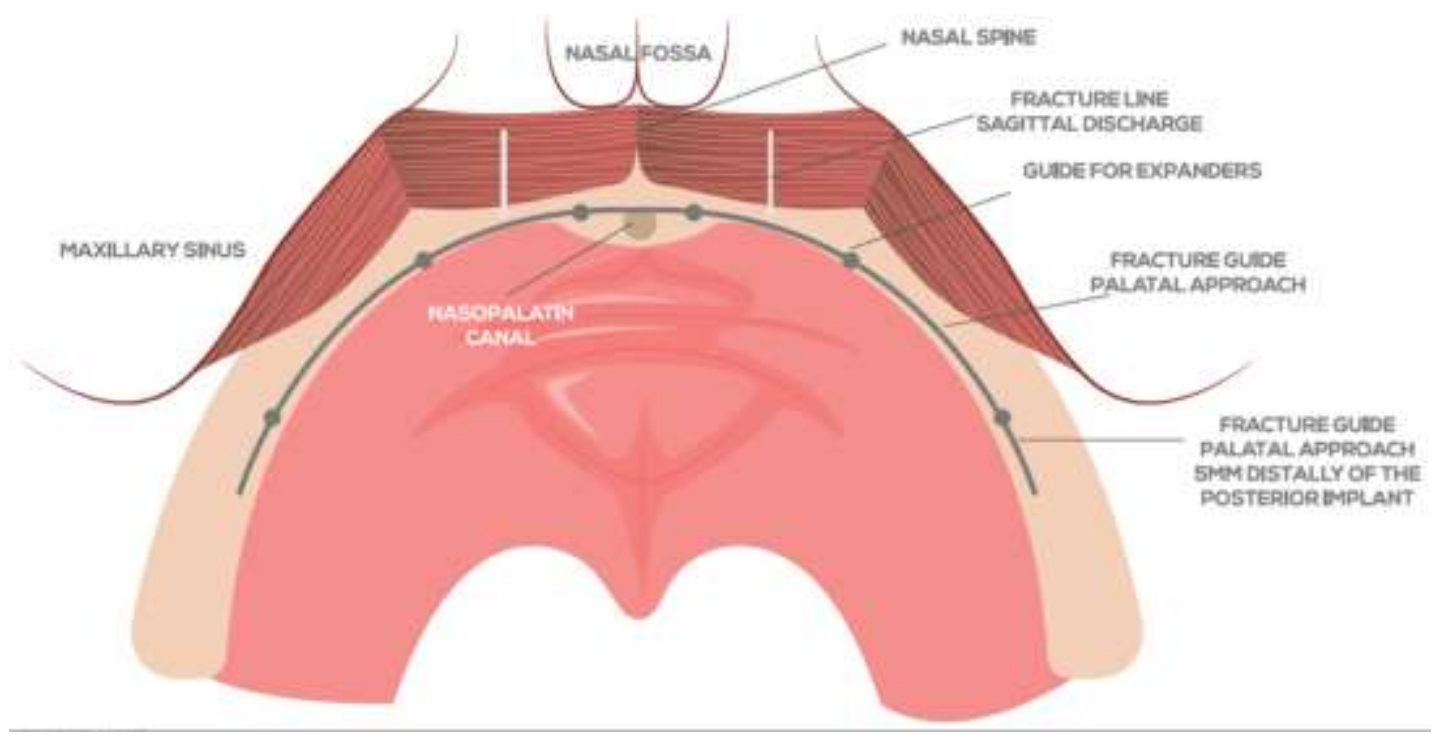

Source: Authors. 
Figure 13. Classification of edentulous maxilla; modified from (Cawood \& Howell, 1988).
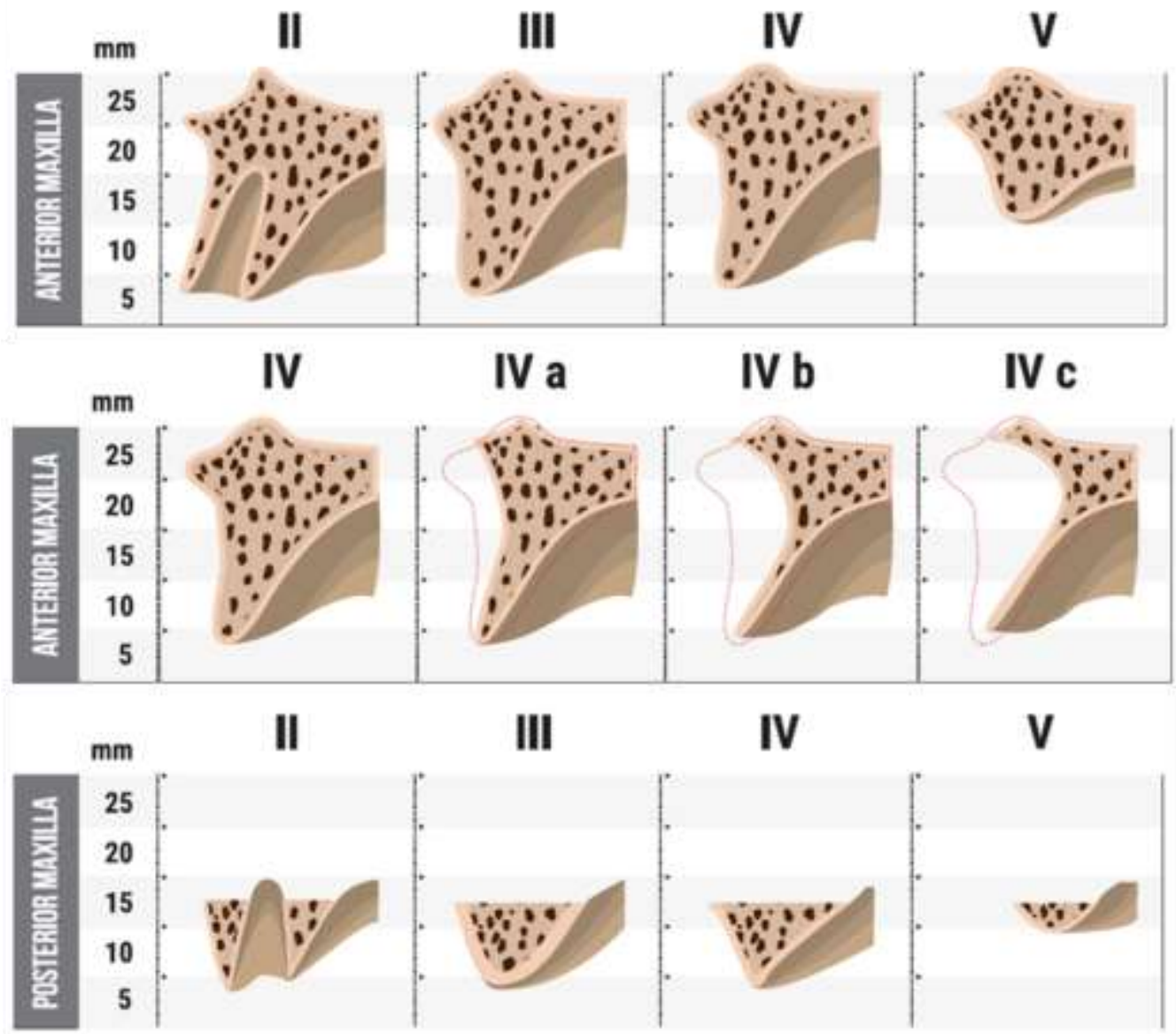

Source: Authors.

In the maxilla, we have a compact bone in the palate with a higher degree of nutrition, especially in the nasopalatine region. Therefore, this is the last region to be resorbed. Another important concept in this technique is that usually, the last tooth to be lost is the canine, leaving an important bone portion that is the last to be resorbed.

In addition, the maxillary sinus and nasal spine region are not two-dimensional but three-dimensional, and the maxillary sinus in its distal and mesial parts and towards the palate creates interesting spaces for dental implant installation. Thus, this multidimensional approach's classification for implant placement is very important (Figs. 12 and 13).

The splitting expansion and palatal approach technique described here can be performed in some implants and the alveolar ridge splitting technique in others in the same surgery when there are limitations. A sinus floor augmentation may also be needed. These are variations of the technique.

When there is not enough bone in the triangular part of the nasal spine, only 4 implants can be installed at canine and molar sites, and there is a need to displace the buccal plate of the anterior nasal spine. The buccal plate is moved in front of the nasopalatine canal, and it remains expanded, supporting both sides.

We recommend clindamycin hydrochloride as antimicrobial therapy for 5 days, starting 1 day before the surgery. Besides, we also prescribe celecoxib and ketorolac for 5 days.

The second surgery occurs after 4 months from the implant placement. When implants are clinically stable at second surgery, the classical prosthetic steps are further undertaken.

This technique allows no thread exposure in the palatal side and decreases the risk of buccal bone plate fracture. It requires surgical skills, knowledge of the bone type and of the surgical anatomy of the region, but it is safe and simple. 
Research, Society and Development, v. 10, n. 8, e26710817214, 2021

(CC BY 4.0) | ISSN 2525-3409 | DOI: http://dx.doi.org/10.33448/rsd-v10i8.17214

There is a need for a detailed computed tomography study before surgery to analyze where ridge expansion may or may not be performed. In the present case, tomographic images before and after implant installation are shown in Figures 14 and 15 .

Figure 14. Tomographic image before implant installation.

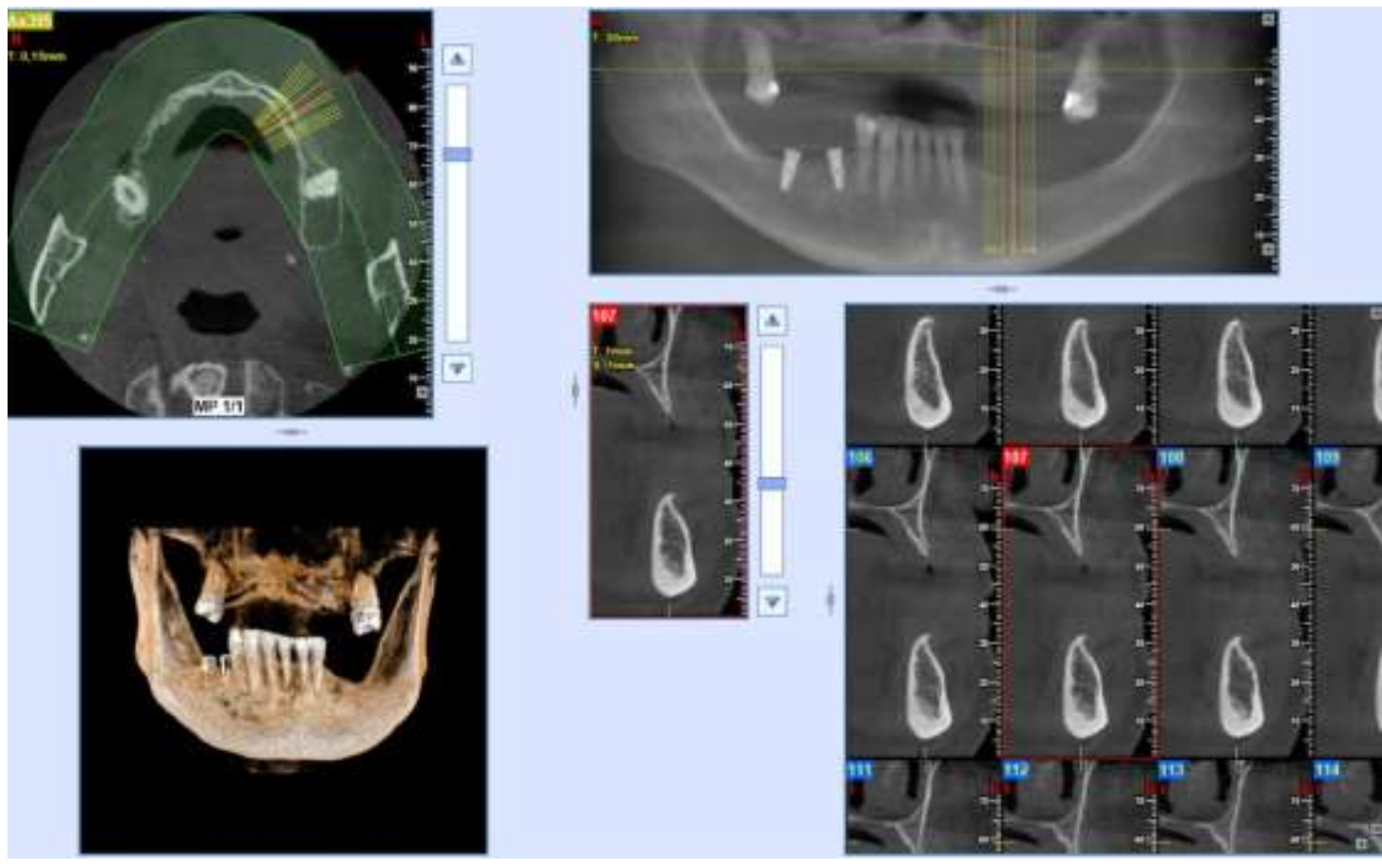

Source: Authors.

Figure 15. Tomographic image after the implant installation.
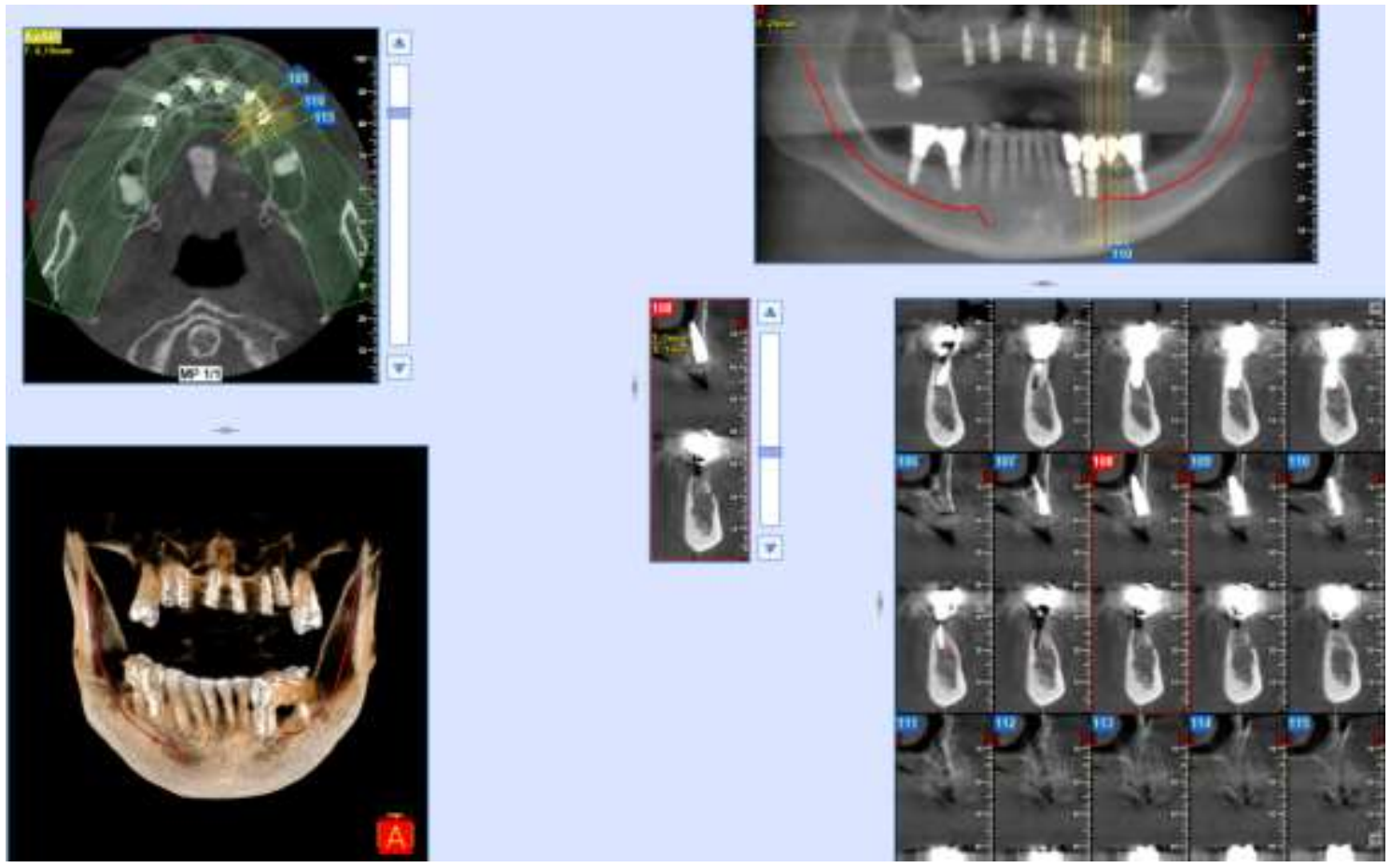

Source: Authors. 


\section{Discussion}

This work aims to describe the splitting expansion and palatal approach technique for treating atrophic maxillary ridges with a horizontal bone deficit using piezosurgery and rehabilitation with implant placement in only one surgical time. This hybrid technique combines the characteristics of two commonly used techniques described in the literature; the alveolar ridge splitting/expansion technique (Bassetti et al., 2016; Blus \& Szmukler-Moncler, 2006; Doimi, Balseca, \& La Torre, 2017; Summers, 1994) and the palatal approach technique (Lekholm et al., 1996).

The advantage of the splitting expansion and palatal approach technique is that implants can be inserted simultaneously as the bone is widened, which reduces morbidity and treatment costs and time (Bassetti et al., 2016; Blus \& Szmukler-Moncler, 2006).

This technique eliminates the need for bone grafts taken from many donor sites like skullcap, iliac crest, maxillary tuberosity or symphysis of the chin, which could cause infections, dehiscences, postoperative morbidity associated with bone harvesting and increase the cost and time of the treatment (Blus \& Szmukler-Moncler, 2006; Felice et al., 2009; Nkenke et al., 2001).

The morphology of the bone defect is an important consideration for the adequacy of the techniques. If the alveolar ridge width is less than $6 \mathrm{~mm}$, transversal bone augmentation is generally required to allow implant installation (Blus \& Szmukler-Moncler, 2006; Santagata, Guariniello, \& Tartaro, 2011). The amount of bone necessary for implant surgery is a consensus in the literature; a minimum of 6 to $7 \mathrm{~mm}$ of bone width is required for placement of an implant with a diameter of 3.5 to $4 \mathrm{~mm}$ using a standard surgical protocol (Adell et al., 1990; Nedir et al., 2004; Nevins \& Langer, 1993). There is need of a bone width of at least 1 to $1.5 \mathrm{~mm}$ on both buccal and palatal sides of the implant (Baffone et al., 2013; Nedir et al., 2004; Scipioni, Bruschi, Calesini, Bruschi, \& De Martino, 1999).

The requirements of bone morphology for this hybrid technique are: an alveolar ridge composed mainly of medullary bone, with a broad base and crest in the form of a knife blade, with sufficient bone height (10 mm at least) and width of 3 to 5 mm (Basa, Varol, \& Turker, 2004; Doimi et al., 2017; Simion et al., 1992); the anterior nasal spine must present a minimum of $3 \mathrm{~mm}$ width and a triangular base; anterior bone volume on the nasal spine of 3 to $4 \mathrm{~mm}$ in front of the nasopalatine canal.

Even after the implant placement, the expansion performed will leave some gaps between buccal and palatal crests. However, it is unnecessary to fill these gaps created with alveolar ridge expansion because bone remodeling will occur (Scipioni, Bruschi, \& Calesini, 1994). The intercortical bone space obtained with this technique is similar to an extraction site that does not require filling with graft, but the periosteum and the matrix are very important in the regenerative process (Doimi et al., 2017; Scipioni et al., 1994). A study in minipigs showed similar bone healing in the gap regions comparing sites with and without graft and membrane (Stricker et al., 2014).

The main advantage of the hybrid technique is that there is no thread exposure on the palatal side, as seen in the palatal approach technique (Lekholm et al., 1996). And the alveolar ridge splitting/expansion technique presents a high fracture rate because drilling and implant placement is performed in the middle of the atrophic ridge (Vercellotti, 2000).

Another advantage of this technique is that the insertion guide portion of the prosthesis is in the palatal region, which favors esthetics. In protocol-type prostheses, the palatal insertion or guide is the best option from the esthetic perspective.

The alveolar ridge splitting technique shows high survival rates and is a predictable alternative for implant placement in narrow alveolar ridges (Bassetti et al., 2016). In addition, the success rates of implants placed with this technique are comparable with those placed in original bone without ridge expansion (Bassetti et al., 2016). Also, a combined osseodensification drilling-alveolar ridge expansion technique showed increased evidence of osseointegration and primary implant stability (Tian et al., 2019). The hybrid technique described in this work still needs a follow-up study to evaluate the 
success rates, but since it follows the principles of two techniques previously established in the literature (Bassetti et al., 2016; Lekholm et al., 1996), the success is likely to be similar.

More research evaluating the outcomes of the implant placement in the atrophic maxilla with this hybrid technique is necessary to verify the bone changes and bone loss, particularly at buccal sites.

\section{Conclusion}

The splitting expansion and palatal approach technique described is an efficient option for treating atrophic maxillary ridges with reduced bone width and rehabilitation with implant placement. In addition, it allows one-step surgery, no need for bone grafts, no thread exposure in the palatal side, and less risk of buccal bone plate fractures in relation to the other techniques.

\section{References}

Adell, R., Lekholm, U., Grondahl, K., Branemark, P. I., Lindstrom, J., \& Jacobsson, M. (1990). Reconstruction of severely resorbed edentulous maxillae using osseointegrated fixtures in immediate autogenous bone grafts. International Journal of Oral and Maxillofacial Implants, 5(3), $233-246$.

Araujo, M. G., \& Lindhe, J. (2009). Ridge alterations following tooth extraction with and without flap elevation: an experimental study in the dog. Clinical Oral Implants Research, 20(6), 545-549. doi:10.1111/j.1600-0501.2008.01703.x

Baffone, G. M., Botticelli, D., Pereira, F. P., Favero, G., Schweikert, M., \& Lang, N. P. (2013). Influence of buccal bony crest width on marginal dimensions of peri-implant hard and soft tissues after implant installation. An experimental study in dogs. Clinical Oral Implants Research, 24(3), 250-254. doi:10.1111/j.1600-0501.2012.02512.x

Basa, S., Varol, A., \& Turker, N. (2004). Alternative bone expansion technique for immediate placement of implants in the edentulous posterior mandibular ridge: a clinical report. . International Journal of Oral and Maxillofacial Implants, 19(4), 554-558.

Bassetti, M. A., Bassetti, R. G., \& Bosshardt, D. D. (2016). The alveolar ridge splitting/expansion technique: a systematic review. Clinical Oral Implants Research, 27(3), 310-324. doi:10.1111/clr.12537

Blus, C., \& Szmukler-Moncler, S. (2006). Split-crest and immediate implant placement with ultra-sonic bone surgery: a 3 -year life-table analysis with 230 treated sites. Clinical Oral Implants Research, 17(6), 700-707. doi:10.1111/j.1600-0501.2006.01206.x

Brandão, T. L., Marao, H. F., Roman-Torres, C. V. G., Sendyk, W. R., \& Pimentel, A. C. (2020). Osseodensification in atrophic maxilla for subsequent installation of dental implants. Research, Society and Development, 9(8), e305985814. https://doi.org/10.33448/rsd-v9i8.5814

Buser, D., Janner, S. F., Wittneben, J. G., Bragger, U., Ramseier, C. A., \& Salvi, G. E. (2012). 10-year survival and success rates of 511 titanium implants with a sandblasted and acid-etched surface: a retrospective study in 303 partially edentulous patients. Clinical Implant Dentistry and Related Research, 14(6), 839851. doi:10.1111/j.1708-8208.2012.00456.x

Cawood, J. I., \& Howell, R. A. (1988). A classification of the edentulous jaws. International Journal of Oral and Maxillofacial Surgery, 17(4), $232-236$.

Doimi, J. R., Balseca, G. M. A., \& La Torre, A. C. (2017). Placement of dental implants in atrophic jaw with divided crest and ridge expansion technique. Revista Odontologica Mexicana, 21(3), 192-198.

Felice, P., Pistilli, R., Lizio, G., Pellegrino, G., Nisii, A., \& Marchetti, C. (2009). Inlay versus onlay iliac bone grafting in atrophic posterior mandible: a prospective controlled clinical trial for the comparison of two techniques. Clinical Implant Dentistry and Related Research, 11 Suppl 1, e69-82. doi:10.1111/j.1708-8208.2009.00212.x

Lekholm, U., Sennerby, L., Roos, J., \& Becker, W. (1996). Soft tissue and marginal bone conditions at osseointegrated implants that have exposed threads: a 5-year retrospective study. . International Journal of Oral and Maxillofacial Implants, 11(5), 599-604.

Nedir, R., Bischof, M., Briaux, J. M., Beyer, S., Szmukler-Moncler, S., \& Bernard, J. P. (2004). A 7-year life table analysis from a prospective study on ITI implants with special emphasis on the use of short implants. Results from a private practice. Clinical Oral Implants Research, 15 (2), $150-157$.

Nevins, M., \& Langer, B. (1993). The successful application of osseointegrated implants to the posterior jaw: a long-term retrospective study. International Journal of Oral and Maxillofacial Implants, 8(4), 428-432.

Nkenke, E., Schultze-Mosgau, S., Radespiel-Troger, M., Kloss, F., \& Neukam, F. W. (2001). Morbidity of harvesting of chin grafts: a prospective study. Clinical Oral Implants Research, 12(5), 495-502.

Santagata, M., Guariniello, L., \& Tartaro, G. (2011). A modified edentulous ridge expansion technique for immediate placement of implants: a case report. Journal of Oral Implantology, 37 Spec No, 114-119. doi:10.1563/AAID-JOI-D-10-00035.1

Schropp, L., Wenzel, A., Kostopoulos, L., \& Karring, T. (2003). Bone healing and soft tissue contour changes following single-tooth extraction: a clinical and radiographic 12-month prospective study. International Journal of Periodontics and Restorative Dentistry, 23(4), 313-323. 
Research, Society and Development, v. 10, n. 8, e26710817214, 2021

(CC BY 4.0) | ISSN 2525-3409 | DOI: http://dx.doi.org/10.33448/rsd-v10i8.17214

Scipioni, A., Bruschi, G. B., \& Calesini, G. (1994). The edentulous ridge expansion technique: a five-year study. International Journal of Periodontics and Restorative Dentistry, 14(5), 451-459.

Scipioni, A., Bruschi, G. B., Calesini, G., Bruschi, E., \& De Martino, C. (1999). Bone regeneration in the edentulous ridge expansion technique: histologic and ultrastructural study of 20 clinical cases. International Journal of Periodontics and Restorative Dentistry, 19(3), 269-277.

Simion, M., Baldoni, M., \& Zaffe, D. (1992). Jawbone enlargement using immediate implant placement associated with a split-crest technique and guided tissue regeneration. International Journal of Periodontics and Restorative Dentistry, 12(6), 462-473.

Stricker, A., Fleiner, J., Dard, M., Voss, P., Sauerbier, S., \& Bosshardt, D. D. (2014). Evaluation of a new experimental model to study bone healing after ridge expansion with simultaneous implant placement--a pilot study in minipigs. Clinical Oral Implants Research, 25(11), 1265-1272. doi:10.1111/clr.12265

Suh, J. J., Shelemay, A., Choi, S. H., \& Chai, J. K. (2005). Alveolar ridge splitting: a new microsaw technique. International Journal of Periodontics and Restorative Dentistry, 25(2), 165-171.

Summers, R. B. (1994). The osteotome technique: Part 2--The ridge expansion osteotomy (REO) procedure. Compendium, 15(4), 422, 424, 426, passim; quiz 436.

Tatum, H., Jr. (1986). Maxillary and sinus implant reconstructions. Dental Clinics of North America, 30(2), 207-229.

Tian, J. H., Neiva, R., Coelho, P. G., Witek, L., Tovar, N. M., Lo, I. C., Gil, L. F., \& Torroni, A. (2019). Alveolar Ridge Expansion: Comparison of Osseodensification and Conventional Osteotome Techniques. The Journal of Craniofacial Surgery, 30(2), 607-610. https://doi.org/10.1097/SCS.0000000000004956

Vercellotti, T. (2000). Piezoelectric surgery in implantology: a case report--a new piezoelectric ridge expansion technique. International Journal of Periodontics and Restorative Dentistry, 20(4), 358-365. 